研 究

粉末アルミニウム合金の切削仕上げ面粗さに対する油棛へのたばこ混入の影響

\author{
多田 吉宏的, 今井 雅希的2 \\ 41 徳島大学工学部機械工学科, $\bar{T} 770-8506$ 徳島市南常三島町 2-1. \\ 山2 怢シーアールイー, テ 460-0022 名古屋市中区金山 1-2-2.
}

\title{
Effect of Contamination of Tobacco to Cutting Fluid on Surface Finish of P/M Aluminum Alloy
}

\author{
Yoshihiro Tada ${ }^{\text {मे1 } 1}$ and Masaki Imai ${ }^{\text {\2 } 2}$ \\ ॠ1 Dept. Mech. Eng., Fac. Eng., Tokushima University, 2-1 Minami-Josanjima, Tokushima 770-8506. \\ ${ }^{\text {म2 }^{2}}$ CRE Co.Ltd., 1-2-2 Kanayama, Naka-ku, Nagoya 460-0022.
}

Received March 4, 2003

\begin{abstract}
SYNOPSIS
Effect of contamination of tobacco to cutting fluid on surface roughness has been investigated in finish turning of $\mathrm{P} / \mathrm{M}$ aluminum alloy and wrought pure aluminum. Tobacco deteriorates the surface finish, so that the experiential knowledge in machining work shops is confirmed. The harmfulness of tobacco appears clearer at good finishing conditions. The deterioration in surface roughness depends on concentration of some tobacco component (s) exuded into cutting fluid; surface roughness is not influenced below a threshold concentration and the deterioration in surface roughness shows saturation at high concentrations. The adverse effect of contamination of tobacco to cutting fluid on surface roughness can be recovered by removing the harmful tobacco component (s) from the fluid by active carbon.
\end{abstract}

\section{KEYWORDS}

surface finish, roughness, tobacco, cutting oil, $\mathrm{P} / \mathrm{M}$ aluminum alloy

\section{1 緒言}

切削加工現場では工具や切削油棛に対する寿命管理の重要 性が言われているが, 環境整備が十分ではない事業所を中心 として切削油剤中へのたばこの吸い殼の湿入がしばしば見受 けられる.その一方で，切削加工現場では，切削油剤中にた ばこの吸い款が混入すると切削仕上げ面のあらさが悪化する 場合のあることも経験的に知られている.アルミニウムは軟 質で切削抵抗の低い材料であるが，凝着性が高く潤滑条件の 影響を受けやすいことから切削油剤の作用に関して多くの研 究息かか行われてきた.しかし，切削油剤中にたばこが湿入した 場合の影響については，わずかに神谷ら ${ }^{5}$ の研究があるのみ でほとんど調查されていないのが実情である。神谷らは純ア ルミニウムの切削仕上げ面粗さに対する切削油剤へのたばこ 混入の影響を調ぺ，不水浴性切削油剤を使用した場合にたば こ混入による仕上げ面粗さの悪化が認められることを報告し ている.しかし，切削油剤へのたばこ混入による仕上げ面粗 さの変化について系統的に調查した研究はほとんど無く，た ばこの悪影響が現れやすい加工条件やその作用メカニズムな どに関して十分なテータの蓄積も知見も無いのが実情である。
そこで，本研究では，粉末アルミニウム合金を主対象とす る旋削仕上げにおいて，たばこの涅入が仕上げ面粗さにどの 程度の影響を及ほしているのかを明らかにすることを試みた。 また，たばこが切削油剤中に混入した場合にその悪影響を避 ける手段についても検討を加えた.

\section{2 試料および実験方法}

被削材には, $\mathrm{Al}-12 \mathrm{Si}-6 \mathrm{Fe}-4.5 \mathrm{Cu}-0.5 \mathrm{Mg}-0.4 \mathrm{Mn}$ の組成を有す る急冷凝固粉末押出し材の高力耐熱アルミニウム合金を用い た.この材料は比較的硬質な材料であるため，軟質で㠜着を 生じやすい純アルミニウムの粉末鍛造材と溶製材A1100を比 較材として使用した。Table 1に示すように，以後の図中では

Table 1 Work materials used in the present experiments.

\begin{tabular}{l|l|c}
\hline \multicolumn{1}{c|}{ Work material } & Abbrev. & Size $(\mathrm{mm})$ \\
\hline $\begin{array}{l}\text { Rapidly solidified Al-12Si-6Fe } \\
\text { 4.5Cu-0.5Mg-0.4Mn }\end{array}$ & AlSiFeCu & $\phi 15$ \\
\hline P/M pure aluminum & P/M Al & $\phi 40$ \\
\hline IMA1100-H14 & A1100 & $\phi 40$ \\
\hline
\end{tabular}


これらをそれぞれ $\mathrm{AlSiFeCu}, \mathrm{P} / \mathrm{M} \mathrm{Al}$ およびA1100と略記して 示す.

本研究で用いた切削油剤はTable 2に示すようなもので，い ずれも鉱油と脂肪酸から構成されて極圧添加剂を含まない不 水溶性切削油剤である．この中で，非鉄合金用として市販さ れている不水溶性切削油剤 (ユシロ化学工業 CG-8) を主に用 いた．また，一部の実験には，スピンドル油を基油としてこ れにオレイン酸およびパーム油を5mass\%添加した自作油も使 用した。たばこはニコチンとタールの表示値の軽重を参考に してTable 3に示すJT製の3銘柄を選択した. たばこの葉の部 分のみを取出して切削油剂中に所定時間浸漬して成分を溶出 させた後，湶過して固形物を取り除いた油剤を使用した。切 削油剂へのたばこ湦入の標準条件は，各切削油剤 1 リットル に対してセブンスターの葉 $1.6 \mathrm{~g}$ (たばこ2本分に相当)を混 入して室温で $12 \mathrm{~h}$ 浸漬したものとした. 以後, 特に断らない 場合には，この標準混入条件で作成した油剤を意味する．な お，たばこの銘柄，混入量および浸漬時間は，必要に応じて 変化させて標準条件以外の混入条件でも実験を行った。

切削は丸棒の旋削(外丸削り)で行い, 切削条件はTable 4の 範团で変化させた.アルミニウムの仕上げ切削を念頭におい て，特に断らない限り切削工具には高すくい角，高逃げ角の ポジティブタィプのバイト(以下, ポジティブ工具)を使用し た. 旋削に際しては，被削材と工具とをアセトンで脱脂した 後, 毎回の切削の直前にネガティブタイプのバイト(以下, ネ ガティブ工貝)により送り $0.078 \mathrm{~mm} / \mathrm{rev}$, 切込み $0.2 \mathrm{~mm}$ の条件 で一層分切削して被削材表面の初期条件の統一を図った. 切 削油剤は常に刃先部分に十分な油剂が供給されていることに 留意しながら刷毛塗りで与えた。

Table 2 Cutting fluids and their abbreviations.

\begin{tabular}{l|c|c}
\hline \multicolumn{1}{c|}{ Cutting fluid } & Abbrev. & Ingredient \\
\hline Commercial cutting oil & CG-8 & JS N1, fatty acid $1 \sim 5 \%$ \\
\hline Spindle oil & SP & ISO VG-10 \\
\hline Spindle oil +Oleic acid & SP+OA & SP+5mass\%OA \\
\hline Spindle oil +Palm oil & SP+PO & SP+5mass $\% \mathrm{PO}$ \\
\hline
\end{tabular}

Table 3 Tobacco used in the present experiments.

\begin{tabular}{l|c|c}
\hline \multicolumn{1}{c|}{ Cigarette } & Tar $(\mathrm{mg})$ & Nicotine $(\mathrm{mg})$ \\
\hline MILD SEVEN Super Lights & 6 & 0.5 \\
\hline Seven Stars & 14 & 1.2 \\
\hline PEACE & 21 & 1.9 \\
\hline
\end{tabular}

Table 4 Turning conditions.

\begin{tabular}{|c|c|}
\hline Cutting velocity $\mathrm{V}$ & $\begin{array}{l}\text { AlSiFeCu; } \quad 0.05 \sim 1.18(\mathrm{~m} / \mathrm{s}) \\
\mathrm{P} / \mathrm{MAl}, \mathrm{A} 1100 ; \quad 0.11 \sim 2.4(\mathrm{~m} / \mathrm{s})\end{array}$ \\
\hline Feed & $0.039 \sim 0.156(\mathrm{~mm} / \mathrm{rev})$ \\
\hline Depth of cut & $0.1 \sim 0.5(\mathrm{~mm})$ \\
\hline Cutting tool & $\begin{array}{l}\text { positive type: }(7,27,20,20,29,1,0.4), \mathrm{K} 10 \\
\text { negative type: }(-6,9,6,6,30,0,0.8), \mathrm{P} 20\end{array}$ \\
\hline
\end{tabular}

旋削後，アセトンで脱脂した被削材の軸方向の中心線平均 あらさ Ra (カットオフ值 $0.8 \mathrm{~mm}$ ) を触針式あらさ計を用いて

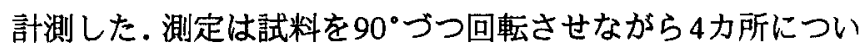
て行い, それらの平均值を旋削による仕上げ面粗さとした. 凝着やむしれなどの突発的な潤滑状態の変化を反映しやすい ことから最大高さあらさRtも併せて計測したが, Raでの傾向 とRtでの傾向には目立った違いは見られなかったため, 最終 的には客観性があって仕上げ面の平均的な状況を反映しやす い中心線平均あらさRaだけを採用した。

\section{3 実験結果およひ考察}

3.1 切削条件を変化させた場合のたばこ混入の影響

たばこ末混入の市販油CG-8とこれに標準混入条件でたばこ を浸漬した油剤を用いて，切削速度，送りおよび切込みの各 切削条件が仕上げ面粗さに及ぼす影響を調查した。使用工具 はボジティブエ具である.

Fig.1は，切削速度による仕上げ面あらさの変化である．溶 製材 $\mathrm{A} 1100$ に比較して急冷凝固粉末押出し材の方が全体的に 粗く，被削材によって仕上げ面あらさに差が見られるが，い ずれの被削材においても切削速度によるあらさの変化は僅か であった.たばこ混入油剤を用いた場合の仕上げ面あらさは， 末混入油剂を用いた場合のあらさを $0.5 \mu \mathrm{m}$ 程度粗い側に平行 移動した形となり，切削油剤へのたばこの混入の影響が明膫 に認められる。

切削油剤に市販油とこれに標準条件でたばこを浸漬した油 剤を用いたときの，送りによる仕上げ面あらさの変化を Fig.2 に示す.工具刃先の軌跡が被削材表面に転写されてできる幾 何学的な最大高さあらさは送りの自乗に比例するのため, 中 心線平均あらさで求めた仕上げ面あらさも送りの増加につれ て粗くなる、いずれの被削材においても，たばこが混入した 切削油剤を用いたときに仕上げ面あらさが大きくなり，たば こが仕上げ面の品位低下をもたらすことが判る.

切込み深さに対する仕上げ面あらさの変化を Fig.3に示す. ここでも溶製材 $\mathrm{A} 1100$ に比較して急冷凝固粉末押出し材の仕

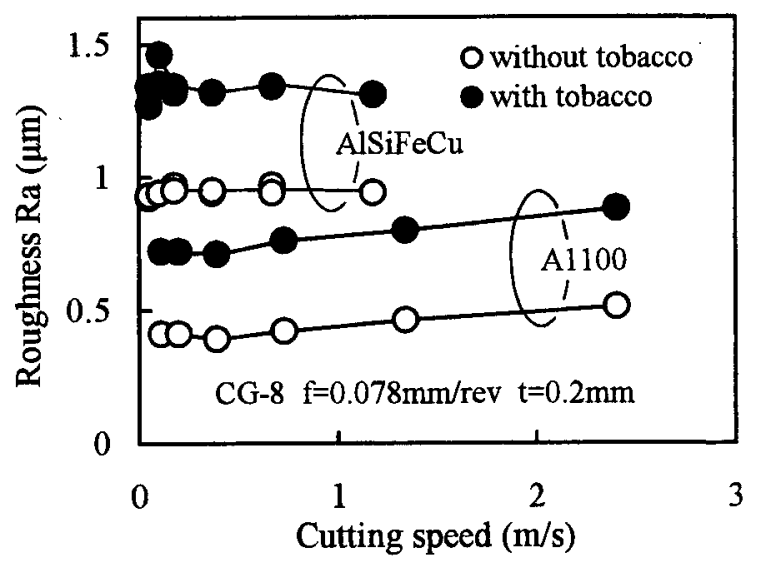

Fig.1 Effects of cutting speed and tobacco contamination on surface roughness. 


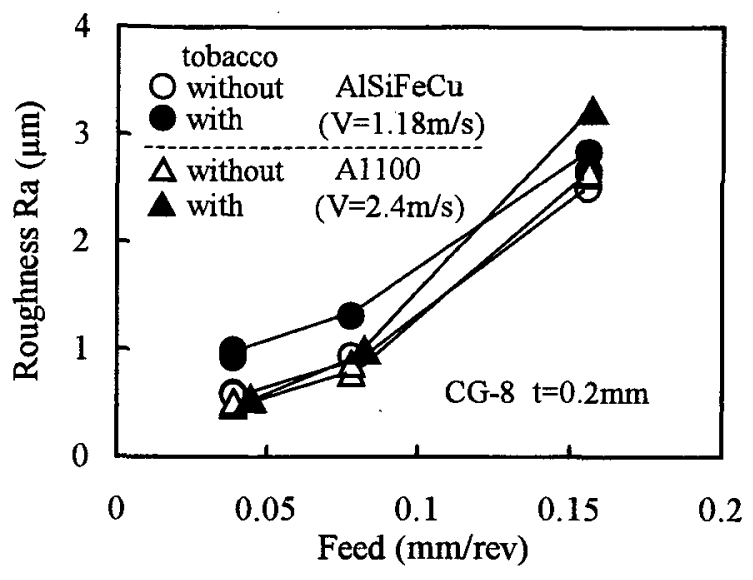

Fig.2 Effects of feed and tobacco contamination on surface roughness.

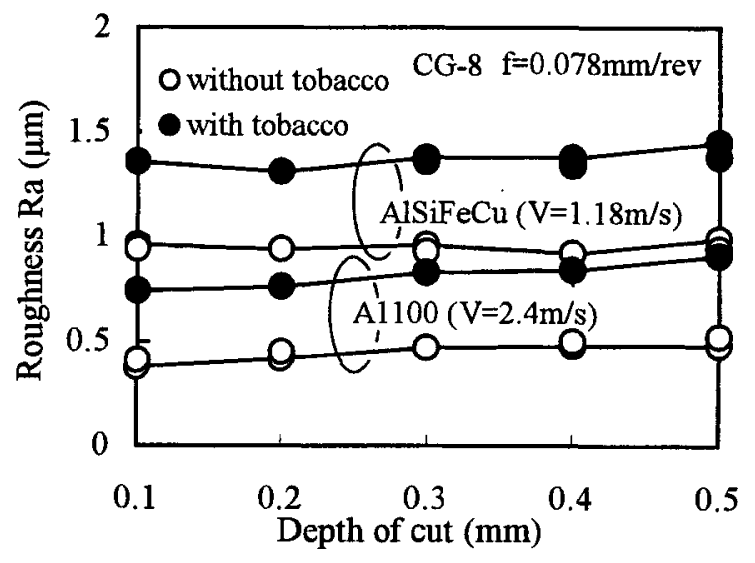

Fig.3 Effects of depth of cut and tobacco contamination on surface roughness.

上げ面あらさが大きいが，実験の範囲では切込みによるあら さの変化は小さい，たばこ混入切削油剤を使用したときの仕 上げ面あらさは，未混入の切削油戍の場合に比較して，いず れの被削材の場合にも約 $0.5 \mu \mathrm{m}$ 大きい值を示した。

アルミニウムの仕上げ切削に適したすくい角拉よび逃げ角 の大きいポジティブ工具を使用したこれまでの実験から，切 削油剤中にたばこが混入することによって仕上げ面あらさが 悪化することが確認された。そこで，切削油剤の特性がより 現われやすい条件として，逃げ面において被削材仕上げ面と の擦過作用の強いネガティブエ具を使用して切削を行った結 果をFig.4に示す.ポジティブエ具に比較してネガティフエ具 での仕上げ面あらさは大きく，またたばこ混入油剤を適用し た際にあらさが大きくなる傾向にある.しかし，ネガティブ 工具自体による仕上げ面あらさの悪化を受けて，切削油剤へ のたばこ湿入の悪影響は相対的に小さくなった．すなわち， 切削油剤へのたばこの混入の影響は，粗加エでは目立ちにく く，仕上げ状態が向上した場合により顕在化しやすいと言え る.このため, 美麗な仕上げ面を求められることの多いアル

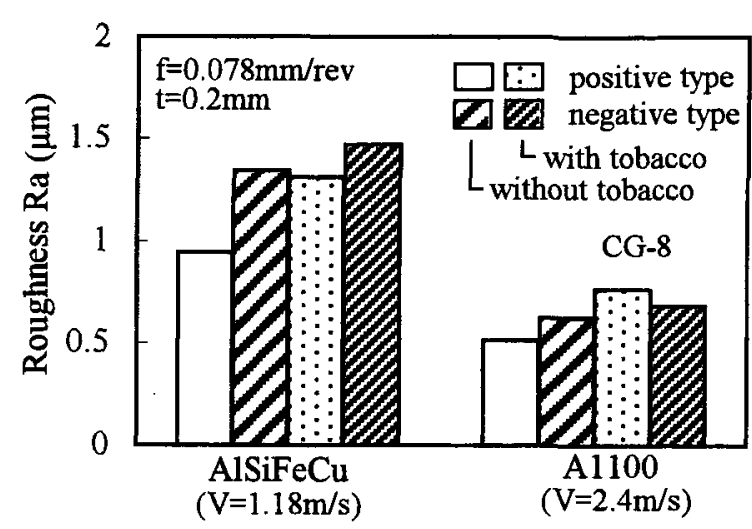

Fig.4 Effects of tool geometry and tobacco contamination on surface roughness.
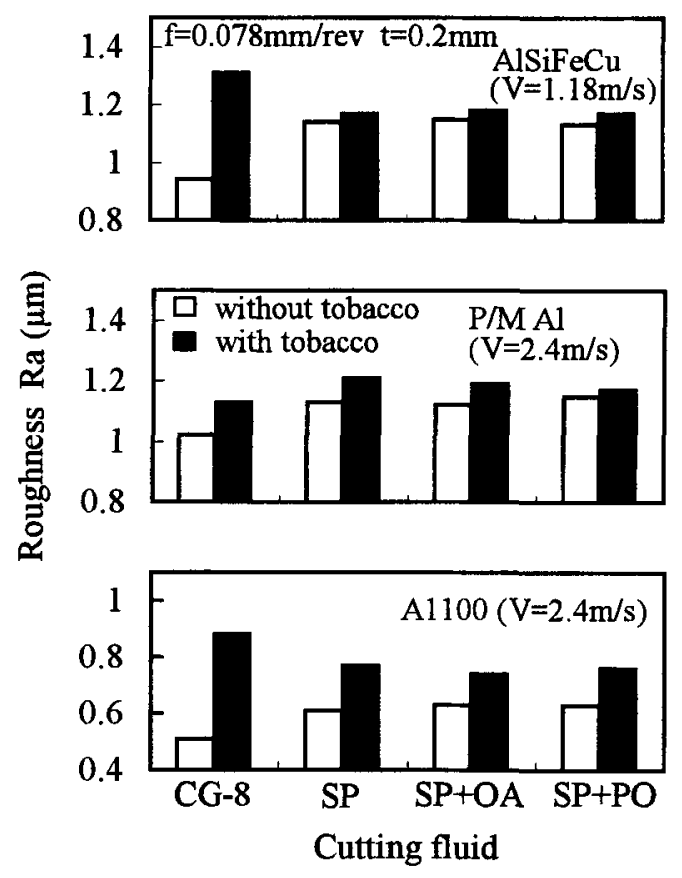

Fig.5 Change in surface roughness by cutting fluid.

ミニウムの仕上げ切削では，切削油剤中へのたばこの混入防 止に留意が必要である。

3.2 たばこの浸漬条件による仕上げ面あらさの変化

不水溶性の市販切削油剤を使用したこれまでの結果から， 切削油剤中へのたばこの混入によって仕上げ面あらさの悪化 が生じることが判った. そこで，切削油戍の種類とたばこの 混入条件が仕上げ面あらさに及ぼす影響を調べた。なお，以降 の切削実験は, ボジティブ工具を使用して送り $0.078 \mathrm{~mm} / \mathrm{rev}$, 切込み $0.2 \mathrm{~mm}$ の条件で行った。

これまでの市販油CG-8以外に自作油も使用して,標準条件 でたばこを混入したときの仕上げ面あらさを調べた. 自作油 はスピンドル油(SP)を基油としてこれにオレイン酸(OA)また はパーム油 $(\mathrm{PO}) を 5 \%$ 添加した鉣油と脂肪酸の混合油剤で, 組 成的には市販油に近い.Fig.5の結果を見ると，たばこ混入の 
影響は市販油でもっとも大きく現われた。これに対して，自 作油では影響が小さく，また脂肪酸の配合および種頑に関わ らずほとんど一定の影響を示した。この傾向は被削材を変え ても同様であった。このことから，たばこから切削油鼡中に 溶出した成分は，被削材であるアルミニウム表面への油剤の 吸着性に影響を及ほしているか，あるいは神谷ら占が指摘す るように基油に何らかの影響を及ぼしている可能性が考えら れ，切削油㖁中に溶出して悪影響をもたらす成分の特定と併 せてその作用メカニスムを今後検討する必要がある.

たばこ(セブンスターツ)の市販切削油剤中での浸漬時間に 対する仕上げ面あらさの変化をFig.6に示す.潤滑性能の少る スピンドル油を用い急冷凝固材を切削したときにはもともと 仕上げ面あらさが粗いため明瞭ではないが, 被削材の種類に よらず，一般に仕上げ面あらさはたばこの浸漬時間の增加に つれてS 字状のカーブを描いて增大した。浸漬時間が $2 \sim 4 \mathrm{~h}$ 以内では仕上げ面あらさの悪化は認められず，また $12 \mathrm{~h}$ 以上 の長時間の浸漬により仕上げ面あらさへのたばこの悪影響は 飽和した. 仕上げ面あらさへのたばこ混入の影響が浸漬時間 に依存することは，それが切削油剤中に溶出した何らかの有 害なたばこ成分の濃度に依存した現象であることを強く示唆 するものである．すなわち，浸漬時間が短く切削油剂中での 有害成分の濃度があるレベルに達しなければ影響は現われず， 闇值が存在するように思われる．浸漬時間の増加により溶出 成分の油剤中での濃度が上がるにつれて仕上げ面あらさは次 第に悪化するが, $12 \mathrm{~h}$ 以上の長時間の浸漬により濃度がある レベルを超えると仕上げ面あらさへのたばこの悪影響は飽和 する.

そこで，たばこの浸漬量または銘柄を変化させて実験を 行った. Fig.7は，たばこの浸漬量をこれまでの2倍に增した 際の仕上げ面あらさの変化である.Fig.6で述べた結果 (白抜 き印)に対して、たばこの投入量を2倍にした場合にはたばこ の影響が浸漬時間の短い段階から現われはじめ，影響の仕方 がより短時間側にシフトしていることが判る。Fig.8は, 市販

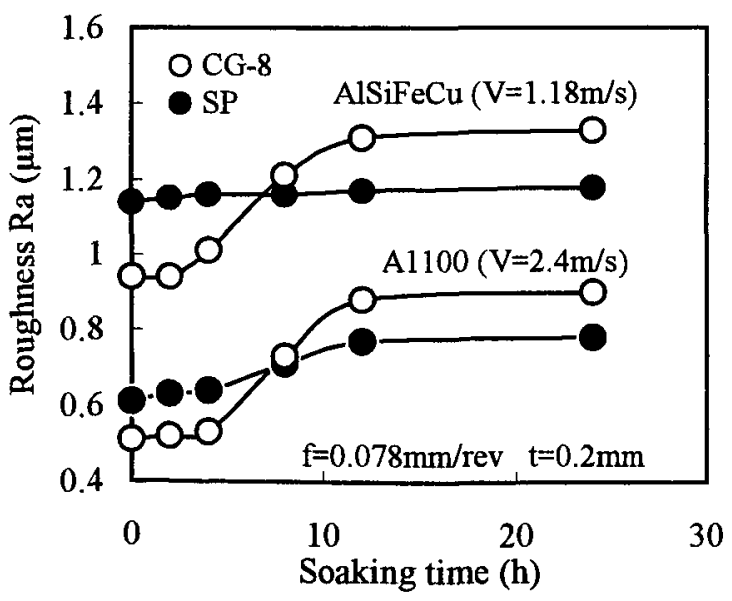

Fig.6 Increase in surface roughness with soaking time of tobacco to cutting fluid.
切削油剂に投入するたばこの銘柄を変えた場合の仕上げ面あ らさを,ニコチン量(表示值)に対してプロットした結果であ る. 本研究ではたばこの影響を明らかにすることに主眼があ り，仕上げ面あらさに悪影響を及ぼす物質の特定は今後の課 題であるが，たばこに含まれるニコチンとタールの量がほぼ 正比例の関係にあることから，本研究での有害成分の含有量 もニコチン量にほほ比例するものと推定した. 図の結果によ れば，浸漬時間が $4 \mathrm{~h}$ と短い場合には、ニコチン量の少ない軽 いたばこでは仕上げ面あらさの增加が少なく、ニコチン量の 多いたばこでは仕上げ面あらさの增加が著しい．すなわち， 有害成分の切削油剤中への溶出量が多いと考えられる重いた ばこになるほど，悪影響が短い浸漬時間からより顕著に現わ れる。しかし，その油中濃度が十分に高くなると考えられる 浸漬時間 $12 \mathrm{~h}$ では，たばこの軽重にかかからず仕上げ面あら さの值は一定となり飽和を示した.たばこの湿入していない 切削油剤を用いたときに比較すると，飽和時の仕上げ面あら さの悪化量は約 $0.4 \mu \mathrm{m}$ であった.

\section{3 たばこ湿入の影響の低減}

これまでの結果より，切削油剤中にたばこが混入すること

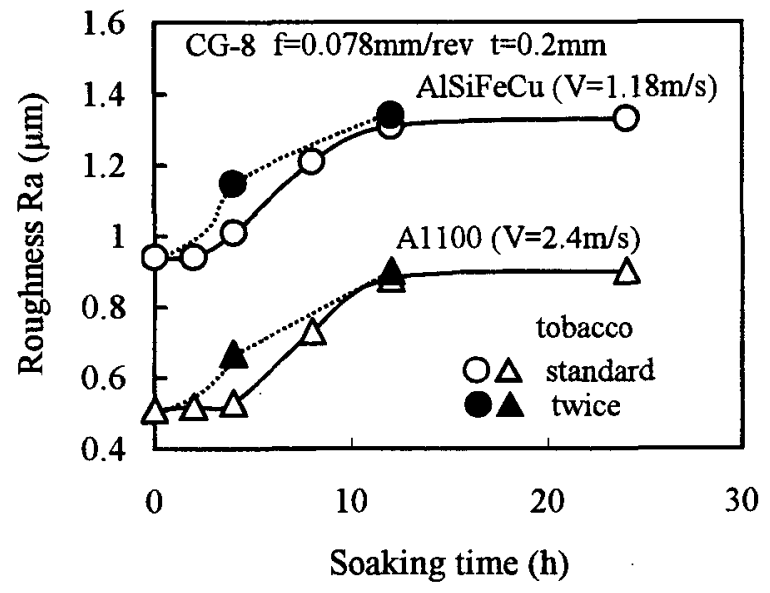

Fig.7 Effects of soaking time and dosage of tobacco on surface roughness.

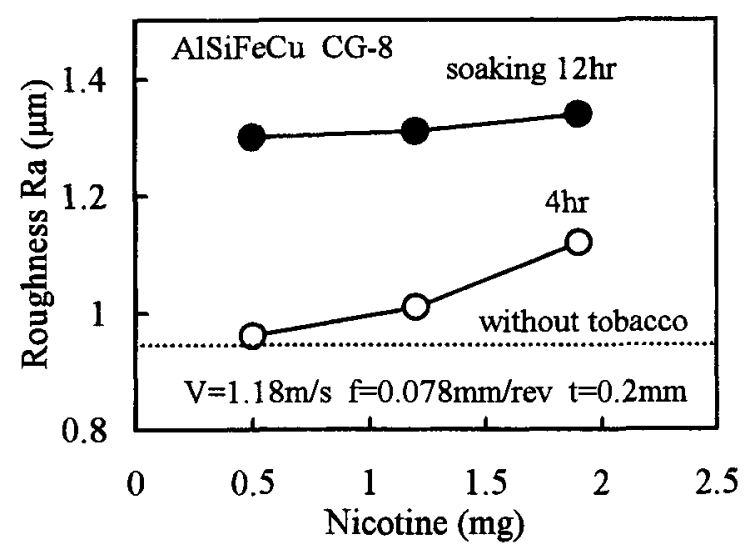

Fig.8 Effects of brand of tobacco expressed by the nicotine content on surface roughness. 


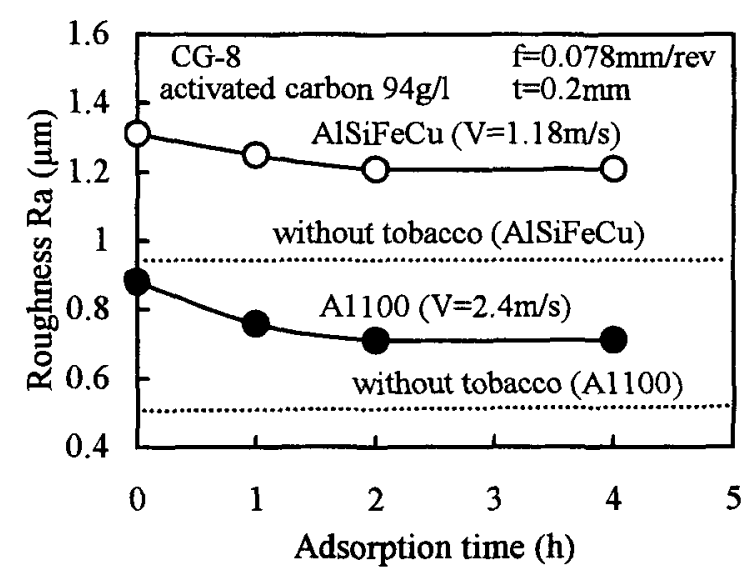

Fig.9 Recovery of surface roughness by activated carbon put into contaminated cutting fluid with tobacco.

によって仕上げ面あらさが悪化することが明らかになるとと もに，その原因物㙺は浸漬中にたばこの葉加ら切削油剤中に 溶出した何らかの成分であることが推測できた。 そこで，そ の有害物質の切削油剂への作用が，油剤に不可逆的な変化を もたらすようなものでないと仮定すれば，その有害物質を切 削油剂中から分離し油剂中での濃度を低下させることで仕上 げ面あらさの悪化を低減できると考えられる．逆に，その有 害物質の油中濃度を下げても仕上げ面あらさへの影響が減少 しなければ，この原因物質は切削油㖁に対して不可逆的な変 化を及ぼしていると考えられる。

そこで，活性炭の吸着作用に着目して，この有害物質の除 去または油中濃度の低下を試みた。たばこを標準条件で混入 した市販油に対して $94 \mathrm{~g} / 1$ (10 mass\%)の活性炭を用いたときの 吸着時間に対する仕上げ面あらさの変化を Fig.9に示す.活性 炭を投入してからの吸着時間の経過に伴い，仕上げ面あらさ 岋回復を示した。一般に，活性炭に限らずどのような吸着材 においても，その吸着能力は吸着時間の経過につれて指数関 数的に低下する。本条件でも吸着時間約 $2 \mathrm{~h}$ 付近から飽和を示 し, 仕上げ面あらさの回復量は約50\%に留まった.しかし,こ の結果より，仕上げ面あらさに悪影響を及ぼすたばこの成分 は活性炭によって吸着除去できる物質であること，および切 削油剂中での有害物質の濃度低下に伴って仕上げ面あらさへ の悪影響を低減できることが確認された，また，たばこの混 入によってその原因物質がひとたび切削油戍中に溶出しても， 活性炭に吸着させてその濃度を下げることにより仕上げ面あ らさが回復することから，このたばこの作用は油剤中の濃度
に依存した可逆な現象であると言える，今後，原因物質の解 明を図る予定である。

$$
4 \text { ま と め }
$$

切削油剤にたばこが混入することによる仕上げ面あらさへ の影響を粉末アルミニウム合金を主対象とする旋削仕上げに おいて調查し，以下のような結論が得られた。

(1) 切削油剂にたばこが混入することにより仕上げ面あらさは 確かに悪化し，従来加工現場で経験的に言われていたこと が立証された。

(2) 仕上げ面あらさへのたばこの悪影響は,上仕上げほど顕在 化しやすい。

(3)この悪影響は切削油剤中に溶出した何らかのたばこ成分の 濃度に依存した可逆な現象であり，油剤中での原因物質の 濃度がある閥值以上の場合に現われ，また高濃度になると 仕上げ面あらさへの影㗽は飽和する。

(4) 切削油剤中の原因物質は活性炭により吸着除去でき,油剤 中での濃度を低下させることによって仕上げ面あらさを回 復することが可能である。

\section{謝辞}

本実験に使用した切削油剤(CG-8)をこ提供頂いたユシロ化 学工業侏に謝意を表します.

\section{文献}

1) 金枝敏明, 河坂博文: “軟質金属切削における塗布効果(第 1 報)発生条件ならびに㳂布剤の境界澌滑特性の影響 ", 精 密工学会誌, 61(1995)702-706.

2) T.Kaneeda and T.Taki: "Lubricant Applying Effect in Aluminum Culting", Proceedings of 5 th International Conference on Progress of Machining Technology, Beijing, (2000)185-190.

3) 池田慎一, 田頭孝介, 中津正志, 佐藤謙司 : "アルミニウム の切削挙動に及ほす流動パラフィン塗布㧩中のオレイン酸 濃度の影響 ", 精密工学会誌, 66(2000)1103-1108.

4) 池田慎一,田頭孝介: "炭素数の異なるカルボン酸の㬁布に よるアルミニウムの切削抵抗の減少 ", 精密工学会誌, 67 (2001)1150-1153.

5) 神谷昌胢,佐々木朋裕, 八高隆雄: "純アルミニウムの被削 性に及ぼす切削液中ニコチンの影響", 軽金属学会第103回 秋期大会講演概要, (2002) 357-358.

6) たとえば, 田中義信，津和秀夫，井川直哉: 精密工作法(上), 共立出版,(1984)59. 